\title{
Private Suits Against States in the Federal Courts
}

State immunity from private suit in the federal courts is a facet of sovereign immunity, that confused and often criticized doctrine which has steadily been weakened by legislative and judicial attack. Unlike federal immunity, or state immunity in state courts, state immunity in federal courts is based at least in part on the eleventh amendment to the Constitution. For this reason it has eroded more slowly than the other varieties. In recent years, however, the Supreme Court has utilized the concept of implied consent to defeat this immunity under certain circumstances. Although the Court earlier had expanded the state's immunity from suit in federal courts beyond the literal scope of the eleventh amendment, recently it has restricted this immunity by imposing a dubious distinction permitting suits based on congressionally created causes of action. This comment examines the implications of this development for traditional state immunity.

\section{Sovereign Immunity, the Eleventh Amendment AND THE Hans Doctrine}

The concept of sovereign immunity-that the king could not be sued in his own courts without his consent-early became part of this country's legal system along with other elements of the common law. ${ }^{1}$ However, since this country rejected both the concept of divine right and the institution of monarchy, courts and commentators have been hard-pressed to justify immunity, ${ }^{2}$ and often rely on the inability to

1 An ancient maxim is generally thought to describe best the conceptual origins of sovereign immunity: "The King can do no wrong." See, e.g., Molitor v. Kaneland Community Unit Dist. No. 302, 18 Ill. 2d Il, 163 N.E.2d 89 (1959). The prohibition was not absolute, however, as relief could be obtained under the common law by a system of petitions. Furthermore, a clear distinction was drawn between suits against the sovereign and suits against officers or agents of the Crown, with different methods and degrees of consent available under the different suits. See generally Jaffe, Suits Against Governments and Officers: Sovereign Immunity, 77 HARv. L. Rev. 1, 2-19 (1963).

2 See, e.g., Muskopf v. Corning Hosp. Dist., 55 Cal. 2d 211, 214-16, 359 P.2d 457, 459-60, 11 Cal. Rptr. 89, 91-92 (1961); Borchard, Government Liability in Tort, 34 Yale L.J. 1 passim (1924); Jaffe, supra note 1, at 19-21. Since monarchy was rejected, the petition of right available in England was never available in America. See id. at 19. 
administer the laws effectively which would supposedly result from permitting suits against the government without severe limitation. ${ }^{3} \mathrm{~A}$ more satisfactory explanation is that many state and local governments fear the depletion of public treasuries. ${ }^{4}$ In any event, the general immunity doctrine has been gradually limited by the courts and legislatures ${ }^{5}$ and retains only vestiges of its former force except in suits by individuals against a state in a federal court. ${ }^{6}$ The vitality of this exception is largely attributable to its constitutional basis.

In 1793 two South Carolina citizens brought an original action in the Supreme Court as executors to collect a debt owed the estate by Georgia. The state refused to appear, denying jurisdiction. The Court in Chisholm v. Georgia ${ }^{7}$ held that its jurisdiction extended to a suit brought against a state by citizens of another state. ${ }^{8}$ There ensued a

3 See, e.g., The Siren, 74 U.S. (7 Wall.) 152, 154 (1868) (Field, J.). Mr. Justice Holmes, in Kawananhoa v. Polyblank, 205 U.S. 349 (1907), offered a theoretical justification by stating that "there can be no legal right as against the authority that makes the law on which the right depends." Id. at 353. This is too broad to be satisfactory since it does not explain the existence of legal rights against the sovereign when it consents to suit, intervenes, or is subject to counterclaim.

4 See, e.g., 1 Warren, The Supreme Court in United States History 91-102 (1922).

5 See, e.g., Golorado Racing Comm'n v. Brush Racing Ass'n, Inc., 136 Colo. 279, 316 P.2d 582 (1957); Hargrove v. Town of Cocoa Beach, 96 So. 2d 130 (Fla. 1957); Molitor v. Kaneland Community Unit Dist. No. 302, 18 Ill. 2d 11, 163 N.E.2d 89 (1959). Mr. Justice Traynor has written: "Only the vestigial remains of such governmental immunity have survived; its requiem has long been foreshadowed. For years the process of erosion of governmental immunity has gone on unabated. The Legislature has contributed mightily to that erosion. The courts, by distinction and extension, have removed much of the force of the rule." Muskopf v. Corning Hosp. Dist., 55 Cal. 2d 211, 221, 359 P.2d 457, 463, 11 Cal. Rptr. 89, 95 (1961).

Legislative restriction of immunity usually takes one of two forms. Some state legislatures specify types of agencies which can be sued or types of causes of action which shall be allowed, See, e.g., LA. Const. art. III, $\$ 35$. Others extend immunity by statute to a small number of state organizations, allowing the courts to conclude that no other organization is immune. See, e.g., ILL. REv. Stat. ch. 37, \& 499 (1965). The Federal Tort Claims Act has substantially limited federal immunity, subject to certain exceptions dealing with discretionary action. 28 U.S.C. $\$ \S 1291,1346,1402,2671-78,2680$ (1964).

6 Suits against states in state courts and suits against the United States are so frequently allowed by actual consent or by resort to suits against officers that the plea of immunity is seldom invoked. See generally Borchard, supra note 2; Jaffe, supra note 1. In suits against states in federal courts, however, pleas of immunity are heard more frequently and succeed more consistently. See, e.g., Great No. Life Ins. Co. v. Read, 322 U.S. 47 (1944); Ex parte New York, No. 1, 256 U.S. 490 (1921).

72 U.S. (2 Dall.) 419 (1793).

8 It was argued on behalf of Georgia that article III, $\S 2$ of the Constitution only contemplated suits in which states were plaintiffs, since the concept of a "sovereign" state's being sued without its consent was so foreign to the common law that it could have played no part in the framing of the Constitution. However, the majority of the Court was convinced that the plain meaning of the Constitution invested federal courts with 
violent reaction among the bar and the general public, ${ }^{9}$ resulting in the prompt adoption and ratification of the eleventh amendment, which effectively reversed Ghisholm. The amendment provides:

The Judicial power of the United States shall not be construed to extend to any suit in law or equity, commenced or prosecuted against one of the United States by Citizens of another State, or by Citizens or Subjects of any Foreign State. ${ }^{10}$

Although some subsequent Supreme Court decisions have expanded and others have limited the scope of the eleventh amendment, ${ }^{11}$ the basic principle remains intact: suits are prohibited when brought against a state by the citizens of another state. ${ }^{12}$ An attempt to take

jurisdiction over the action. Because each Justice entered a separate opinion, with only Mr. Justice Iredell dissenting, it is difficult to define the reasoning behind the Court's decision.

- Sce Corwin, The Constirution 238 (1954); Livingston, Federalism and Constitutional Change 202 (1956); I WARREN, op. cit. supra note 4, at 96-101. Much of this consternation was undoubtedly due to the fact that the foremost proponents of the Constitution had, in preratification days, expressly denied that article III, § 2, which provided that "the judicial Power shall extend ... to Controversies ... between a State and Citizens of another State," would have the effect the Court gave it in Chisholm. See id. at 96.

10 U.S. CoNST. amend. XI. The amendment refers neither to sovereignty nor to immunity, but involves both. It is phrased in terms of federal court jurisdiction and deals with the allocation between the federal government and the states of judicial power to decide certain cases. The underlying considerations are therefore those of federalism. However, the amendment indirectly involves immunity. Although there may be a technical difference between contesting a suit on the basis of an alleged lack of jurisdiction and entering a plea of sovereign immunity, the effect is the same: a federal court may not enter a judgment against the state in either case. Furthermore, the language of the amendment, literally read, suggests problems of subject matter jurisdiction which do not arise in practice. Although it is basic that parties may not waive defects in subject matter jurisdiction, the ability of the state to waive the protection of the eleventh amendment has never been seriously contested. Either the question is one of the identity of parties rather than subject matter, or the rule prohibiting waiver of defects in subject matter jurisdiction has been ignored in favor of the historic ability of the state to waive its immunity. In any case, the power to waive immunity is well established. See, e.g., Clark v. Barnard, 108 U.S. 436 (1883).

11 See, e.g., Principality of Monaco v. Mississippi, 292 U.S. 313 (1934) (suits by foreign countries as well as by their citizens barred); United States v. Texas, 143 U.S. 621 (1892) (no immunity where suit is brought by United States); In re Ayers, 123 U.S. 443 (1887) (state need not be the party of record to be immune; suit against an officer); Clark v. Barnard, 108 U.S. 436 (1883) (state can waive by voluntary submission to suit); New Hampshire v. Louisiana, 108 U.S. 76 (1883) (immunity valid where plaintiff state acts merely as agent for the collection of its citizens' debts). A major development in this area, made without reference to the eleventh amendment, was the permission of suits to restrain state officers from acting ultra vires or pursuant to an unconstitutional statute. The officer is deemed to be stripped of his official capacity and to be acting individually. E.g., Ex parte Young, 209 U.S. 123 (1908). Such actions may be mandatory as well as prohibitory, but monetary damages are not recoverable. See generally Davis, Suing the Government by Falsely Pretending To Sue an Officer, 29 U. CHI. L. REv. 435 (1962).

12 See, e.g., In re Ayers, 123 U.S. 443 (1887); Hagood v. Southern, 117 U.S. 52 (1886); Hollingsworth v. Virginia, 3 U.S. (3 Dall.) 378 (1798). Cf. Louisiana v. Jumel, 107 U.S. 711 (1882). 
advantage of the failure of the amendment expressly to prohibit suits by citizens of the same state was made in Hans $v$. Louisiana. ${ }^{13}$ The plaintiff, a Louisiana citizen, held $\$ 87,500$ in coupons annexed to bonds issued by Louisiana, which later repudiated its obligations under the bonds. ${ }^{14}$ The plaintiff sued in a federal court and invoked the court's federal question jurisdiction by alleging that the state's revocation of its obligations violated article I, section 10 of the Constitution, ${ }^{15}$ which prohibits a state from passing any law impairing the obligation of contracts. The suit was dismissed for want of jurisdiction, ${ }^{16}$ and the Supreme Court affirmed.

Hans clearly held that federal courts do not have jurisdiction over a suit against an unconsenting state brought by its own citizen even when the case arises under the Constitution or laws of the United States. The basis for the decision, however, is unclear. Mr. Justice Bradley, writing for the majority, discussed at length the background of the eleventh amendment and implied that it prohibits such suits in spirit, even though not expressly. ${ }^{17}$ There was also a strong implication, however, that the state's immunity in this case was "inherent in the nature of sovereignty"18 and would be sustained even without the eleventh amendment. The opinion does not make clear whether the holding of Hans was intended as a judicial expansion of the eleventh amendment, as a commentary on article III, section 2 of the Constitution read in the light of the eleventh amendment, ${ }^{19}$ or as a definitive statement of the common law of sovereign immunity.

The question is important. If the immunity is based on the common law it may be directly limited or even abrogated by judicial decision. If the immunity is constitutional, however, judicial efforts to limit its application must be much more cautious. The best view would seem to be that the immunity provided by Hans is based on the common law. The eleventh amendment clarifies article III, section

13134 U.S. 1 (1890).

$14 I d$. at 2 .

$15 I d$. at 3 .

1624 Fed. 55 (C.C.E.D. La. 1885).

17 "Can we suppose that, when the Eleventh Amendment was adopted, it was understood to be left open for citizens of a State to sue their own state in the federal courts, whilst the idea of suits by citizens of other states, or of foreign states, was indignantly repelled? Suppose that Congress, when proposing the Eleventh Amendment, had appended to it a proviso that nothing therein contained should prevent a State from being sued by its own citizens in cases arising under the Constitution or laws of the United States: can we imagine that it would have been adopted by the States? The supposition that it would is almost an absurdity on its face." 134 U.S. at 15.

18 Id. at 13.

19 "The truth is, that the cognizance of suits and actions unknown to the law, and forbidden by the law, was not contemplated by the Constitution when establishing the judicial power of the United States." Id. at 15. 
2 of the Constitution by providing that federal judicial power "shall not be construed to extend" to two types of suits. That a third typea citizen suing his own state-was not mentioned does not, of course, require the conclusion that such an action is approved. Prior to Chisholm v. Georgia it was assumed that the new federal court system did not alter traditional common law applications of sovereign immunity. ${ }^{20}$ When that case reached a contrary result as to citizens of another state, the immunity was made explicit by a constitutional amendment. On the other hand, suits by citizens against their own state or sovereign were familiar at common law, and immunity was the rule. Immunity was so much taken for granted that the possibility that states could be sued in the newly created federal forum was probably not considered at all. This conclusion is supported by the fact that federal courts at that time did not possess general federal question jurisdiction. ${ }^{21}$ Thus, Hans can best be explained as based either implicitly or explicitly on the states' common law immunity.

Federal case law subsequent to Hans has not attempted to clarify the source of the immunity. Nearly all of the cases which have relied on Hans have tended to regard it as a part of the eleventh amendment and thus constitutional in nature. ${ }^{22}$ The Hans doctrine has consistently been enforced in a wide range of cases involving federal questions,

20 See, e.g., id. at 11-18.

21 Not until 1875 was general federal question jurisdiction extended to the federal courts. Act of March 3, 1875, ch. 137, § 1, 18 Stat. 470. Thus, the problems of concurrent jurisdiction were fewer.

22 "[W] $]$ must give to the Eleventh Amendment all the effect it naturally would have, without cutting it down or rendering its meaning any more narrow than the language, fairly interpreted, would warrant. It applies to a suit brought against a State by one of its own citizens as well as to a suit brought by a citizen of another state. Hans $v$. Louisiana, 134 U.S. 1." Ex parte Young, 209 U.S. 123, 150 (1908). Similarly broad statements are frequent. See United States v. Mississippi, 380 U.S. 128, 140 (1965); Ford Motor Co. v. Department of Treasury of Ind., 323 U.S. 459, 464 (1945); Chandler v. Dix, 194 U.S. 590, 591 (1904); Scott v. Board of Supervisors, 336 F.2d 557, 558 (5th Cir. 1964); Skokomish Indian Tribe v. France, 269 F.2d 555, 560 (9th Cir. 1959); Union Trust Co. v. Stearns, 119 Fed. 790, 791 (C.C.D.R.I. 1903); Smith v. Rackliffe, 87 Fed. 964, 968 (9th Cir. 1898); DeLong Corp. v. Oregon State Highway Comm'n, 233 F. Supp. 7, 17 (D. Ore. 1964), aff'd, 343 F.2d 911 (9th Cir. 1965); Blair Holdings Corp. v. Rubenstein, 133 F. Supp. 496, 502 (S.D.N.Y. 1955). But see McCartney v. West Virginia, 156 F.2d 739, 740 (4th Cir. 1946), in which the court stated: "This immunity, at least with respect to actions brought by citizens of the state sued, does not arise from the restriction of the 11th Amendment .... Rather, it comes from what Hamilton described in the Federalist as the inherent . . . nature of sovereignty not to be amenable to the suit of an individual without its consent.' This rule was laid down in unmistakable terms in Hans v. Louisiana. . . ." See also Judge Brown's concurring opinion in Parden v. Terminal Ry. of Ala. State Docks Dep't, 3Il F.2d 727, 734 (5th Cir. 1963): "Sovereign immunity, threadbare as it generally is, is recognized in law. It may, as it does here, deny effectual enforcement to a clear legal right. But that does not raise this notion to the stature of a federal constitutional right." 
most of them constitutional rather than statutory. ${ }^{23}$ Its force has been equal to that of the express prohibition of the eleventh amendment against suits by citizens of another state or country in the federal courts.

\section{WAIVER OF IMmUNity-The INTRODUction OF IMPLIED CONSENT}

The traditional judicial approach to the question of waiver of immunity or consent by a state to suit has taken several forms, but all forms share a common purpose: the protection of the state's ability to grant or withhold consent entirely at its pleasure. The following rules of construction are used to accomplish this purpose. A finding of consent to suit "could only be warranted if exacted by the most express language or by such overwhelming implication from the text as would leave no room for any other reasonable construction."24 Whether such a statement or implication exists must be determined by the law of the particular state. ${ }^{25}$ The consent or waiver must approximate a voluntary abandonment of a known right or privilege. ${ }^{26}$ A statute will not be construed to limit any of the sovereign's preexisting rights or privileges without express language to that effect. ${ }^{27}$ Moreover, even if a state has consented generally to be sued, it has not necessarily consented thereby to be sued in a federal court. ${ }^{28}$

The Supreme Court has recently made substantial changes in this field, and these rules no longer have unqualified application. The pro-

23 The Hans doctrine has been extended to a wide range of situations. See Ex parte New York, No. 1, 256 U.S. 490 (1921) (admiralty); Duhne v. New Jersey, 251 U.S. 311 (1920) (action to enjoin the enforcement of the eighteenth amendment); Smith v. Reeves, 178 U.S. 436 (1900) (action to recover taxes); Fitts v. McGhee, 172 U.S. 516 (1899) (suit alleging deprivation of property without due process); North Carolina v. Temple, 134 U.S. 22 (1890) (seeking affirmative relief from a special tax); Scott v. Board of Supervisors of La. State University, 336 F.2d 557 (5th Cir. 1964) (tort); Skokomish Indian Tribe v. France, 269 F.2d 555 (9th Cir. 1959) (suit alleging deprivation of property in violation of treaty); DeLong Corp. v. Oregon State Highway Comm'n, 233 F. Supp. 7 (D. Ore. 1964), aff'd, 343 F.2d 911 (9th Cir. 1965) (action for declaration of rights and obligations under a contract). The only escape from Hans, as from the eleventh amendment, lay in suing an officer under the appropriate fictions of such suits. See note 11 supra.

24 Murray v. Wilson Distilling Co., 213 U.S. 151, 171 (1909); cf. Chandler v. Dix, 194 U.S. 590 (1904).

25 See, e.g., Ford Motor Co. v. Department of Treasury of Ind., 323 U.S. 454 (1945).

26 This concept is imported from habeas corpus cases such as Johnson v. Zerbst, 304 U.S. 458 (1938), and Fay v. Noia, 372 U.S. 391 (1963), which are frequently cited as upholding the proposition that such a rule of construction is applicable in sovereign immunity cases. See, e.g., Parden v. Terminal Ry. of Ala. State Docks Dep't, 377 U.S. 184, 200 (1964) (dissenting opinion).

27 United States v. UMW, 330 U.S. 258, 272 (1947); United States v. Herron, 87 U.S. (20 Wall.) 251, 255 (1873).

28 See, e.g., Murray v. Wilson Distilling Co., 213 U.S. 151, 172 (1909). 
logue to this change was Petty v. Tennessee-Missouri Bridge Comm'n.9 The plaintiff, a resident of Tennessee, sued in the federal district court under the Jones Act to recover compensation for the death of her husband, who had died while working aboard one of the defendant's ferry boats. The defendant was a bi-state agency created by an interstate compact between Tennessee and Missouri and approved by Congress pursuant to article I, section 10 of the Constitution. The compact provided that the commission would build a bridge over and operate ferries at given points across the Mississippi River. The commission was given power "to contract, to sue and be sued in its own name." 30 Congress, in approving the compact, attached a proviso that the terms of the compact would not be construed "to affect, impair, or diminish any right, power or jurisdiction of . . . any court ... of the United States, over or in regard to any navigable waters, or any commerce between the States...." 31 The lower court's dismissal of the suit for lack of jurisdiction ${ }^{32}$ was reversed by the Supreme Court.

The fact that there would have been no waiver of immunity under either Missouri or Tennessee law ${ }^{33}$ did not deter the Court in Petty any more than did the well-established proposition that sue-and-besued clauses are construed as giving consent to suit in state, not federal, courts. ${ }^{34}$ The Court found that since the "waiver" was contained in an interstate compact its interpretation was a matter of federal law. ${ }^{35}$ The Court interpreted the congressional proviso as a deliberate reservation of jurisdiction and hinted that action by the states under the compact after it had been approved with such a reservation was important in determining that the states had consented to suit. ${ }^{36}$ Congress "approved a sue-and-be-sued clause in a compact under conditions that make it clear that the States accepting it waived any immunity from suit which they otherwise might have." 37

29359 U.S. 275 (1959).

30 Id. at 277.

31 Tennessee-Missouri Bridge Comm'n Compact, ch. 758, 63 Stat. 930 (1949).

32 The Eighth Circuit, in affirming the trial court's dismissal of the suit for lack of jurisdiction, held (1) that the defendant was an instrumentality of both Tennessee and Missouri, not a separate entity, (2) that neither state, expressly or by its courts' interpretations of "sue-and-be-sued" clauses, had consented to suit in tort, and (3) that by virtue of the eleventh amendment the plaintiff could not sue Missouri in a federal court, nor could she sue Tennessee by virtue of Hans $v$. Louisiana. Petty v. Tennessee-Mo. Bridge Comm'n, 254 F.2d 857 (8th Cir. 1958).

33359 U.S. at 279 .

34 See, e.g., Murray v. Wilson Distilling Co., 213 U.S. 151, 171 (1909).

35359 U.S. at 280.

36359 U.S. at $280-81$.

37 Id. at 280. Mr. Justice Frankfurter, whom Justices Harlan and Whittaker joined in dissenting, was not persuaded by the congressional proviso since, as he pointed out, it was 
The Petty decision represents a departure from the traditional approach to state consent described above both in its application of federal law to the issue of consent and in its suggestion that state action in a field over which Congress has reserved jurisdiction might weigh heavily in the finding of consent. Cases involving such factors as sueand-be-sued clauses and interstate compacts are rare, however, and it was possible in Petty to point to specific language, known and acted upon by the states, which indicated waiver. ${ }^{38}$ These same contentions could not be made in Parden v. Terminal Ry. of Alabama State Docks Dep't. ${ }^{39}$

The petitioners in Parden, citizens of Alabama, sued the respondent state-owned railway in the federal district court in Alabama seeking damages under the Federal Employers' Liability Act for injuries sustained while employed by the railway. It was not disputed that the railway was a common carrier for hire in interstate commerce, that it was operated for profit pursuant to Alabama statutes, and that it was wholly owned and operated by the State of Alabama through its State Docks Department. No facts concerning the injuries were disputed. Alabama appeared specially in the district court and moved to quash the summons on the ground that the court lacked jurisdiction since Alabama had not waived its sovereign immunity by consenting to suit. The motion was granted and the court of appeals affirmed, ${ }^{40}$ but the Supreme Court reversed and held that the state's operation of a com-

a standard insertion in approval of such compacts and was not, as legislative history showed, aimed at overcoming immunity from suit. Id. at 285-89.

38 Subsequent federal question cases have been distinguished from Petty on the grounds that they involved no sue-and-be-sued clause in an interstate compact. See Skokomish Indian Tribe v. France, 269 F.2d 555 (9th Cir. 1959) (quiet title suit involving the construction of treaty between United States and Indian tribe; waiver of state's immunity determined by state law); DeLong Corp. v. Oregon State Highway Comm'n, 233 F. Supp. 7 (D. Ore. 1964), aff'd, 343 F.2d 911 (9th Cir. 1965) (declaratory judgment action to interpret contract for construction of interstate bridge; waiver of state's immunity determined by state law). See also J. Ray McDermott \& Co. v. Department of Highways, State of La., 267 F.2d 317 (5th Cir. 1959) (federal admiralty jurisdiction; waiver of state immunity determined by state law); Gross v. Washington State Ferries, 59 Wash. 2d 241, 367 P.2d 600 (1961) (action based on Jones Act and general maritime law; waiver of state immunity determined by state law).

Petty, of course, has not been used to find waiver by federal courts exercising diversity jurisdiction. See Southern Ry. v. South Carolina State Highway Dep't, 246 F. Supp. 435 (E.D.S.C. 1965); Zeidner v. Wulfrost, 197 F. Supp. 23 (E.D.N.Y. 1961); Weyerhaeuser Co. v. State Rds. Comm'n of Md., 187 F. Supp. 766, 771 (D. Md. 1960). Nor has Petty been used to avoid state immunity in federal admiralty court suits under state created causes of action. In re Nueces County, Texas, Road Dist. No. 4, 174 F. Supp. 846, 856 (S.D. Tex. 1959).

39377 U.S. 184 (1964).

40311 F.2d 727 (5th Cir. 1963). 
mon carrier railroad in interstate commerce constituted waiver of its sovereign immunity and consent to suits brought by its employees in the federal courts under the FELA.

The situation in Parden presented no possibility of informed and deliberate consent, for Alabama's constitution, unlike those of most other states, prohibits the state's being made a defendant in any court of law or equity. ${ }^{41}$ The Alabama Supreme Court has consistently held that neither the state legislature nor any state officer can waive the state's immunity or consent to suit. ${ }^{42}$

Mr. Justice Brennan, writing for a bare majority, conceded that Alabama was protected by the doctrine of sovereign immunity from suit without its consent, but concluded that Alabama had consented to this suit. ${ }^{33}$ The issues were posed as follows: "(l) Did Congress in enacting the FELA intend to subject a State to suit in these circumstances? (2) Did it have the power to do so, as against the State's claim of immunity?" 44 Both questions were answered in the affirmative.

The Court first noted that it had previously held both the Federal Safety Appliance $\mathrm{Act}^{45}$ and the Railway Labor Act ${ }^{48}$ applicable to state-owned railroads. Those decisions did not involve immunity, however, since neither act is enforceable by private suit. The Court then pointed out that the language of the FELA is at least as broad as that of the Federal Safety Appliance Act and the Railway Labor Act. ${ }^{47}$ The Court argued that "to read a 'sovereign immunity exception' into the Act would result . . . in a right without a remedy" 48 for one class of

41 Ala. Const. art. I, § 14.

42 See, e.g., State Tax Comm'n v. Commercial Realty Co., 236 Ala. 358, 361, 182 So. 31, 35 (1938); Dunn Constr. Co. v. State Bd. of Adjustment, 234 Ala. 372, 376, 175 So. 383, 386 (1937).

43377 U.S. at $186,192-93$.

44 Id. at 187.

45 United States v. California, 297 U.S. 175 (1936).

46 California v. Taylor, 353 U.S. 553 (1957).

47377 U.S. at 189. The relevant section of the FELA provides: "Every common carrier by railroad while engaging in commerce between any of the several States or Territories ... shall be liable in damages to any person suffering injury while he is employed by such carrier in such commerce . . . "53 Stat. 1404 (1939), 45 U.S.C. \& 51 (1964).

The Court in Parden pointed out that the decision in California v. Taylor, 353 U.S. 553 (1957), was based in part on three lower court decisions holding "that the FELA did authorize suit against a publicly owned railroad despite a claim of sovereign immunity." 377 U.S. at 189. The only one of these three suits which was in a federal court involved a claim of immunity based on state law involving municipalities, not on Hans or the eleventh amendment. Mathews v. Port Util. Comm'n, 32 F.2d 913 (E.D.S.C. 1929). The other two cases were in state courts and could not have involved the type of immunity claimed in Parden. Maurice v. State, 43 Cal. App. 2d 270, 110 P.2d 706 (Dist. Ct. App. 1941); Higginbotham v. Public Belt R.R. Comm'n, 192 La. 525, 188 So. 395 (1938).

48377 U.S. at 190. 
employees since it would mean finding that Congress had made every interstate railroad liable to its injured employees but left those whose employers happened to be state owned without a guaranteed forum in which to enforce such liability. "We are unwilling to conclude that Congress intended so pointless and frustrating a result." 49

Alabama claimed immunity under the Hans doctrine, arguing that it was a constitutional rule which could not be changed by Congress in the FELA. ${ }^{50}$ A finding that the Hans doctrine was a matter of common law would have refuted this contention, since Congress has power to change the common law by legislation. However, the Court, probably anticipating future cases, did not make such a declaration but rather argued from both points of view.

Assuming that Alabama's immunity was based on common law, the Court first reasoned that while a state may not be sued by an individual without its consent.

By adopting and ratifying the Commerce Clause, the States empowered Congress to create such a right of action against interstate railroads; by enacting the FELA in the exercise of this power, Congress conditioned the right to operate a railroad in interstate commerce upon amenability to suit in federal court as provided by the Act; by thereafter operating a railroad in interstate commerce, Alabama must be taken to have accepted that condition and thus to have consented to suit. ${ }^{51}$

The Court's argument concerning the surrender of sovereignty by the ratification of the commerce clause ${ }^{52}$ is superficially compelling but presents problems of consistency; if it could succeed in Parden it should have succeeded in Hans $v$. Louisiana. ${ }^{53}$ It cannot be argued

$49 \mathrm{Ibid}$. There are two ways to approach the question of congressional intent in Parden. Mr. Justice Brennan pointed out that a class of potential defendants was named and that no exceptions were made. From this fact he reasoned that Congress intended to include states in that class. Mr. Justice White, dissenting, maintained that settled rules of construction compelled the conclusion that states were not included since they were not mentioned. It appears that no state was operating a common carrier railroad when the FELA was enacted, and it is therefore impossible to determine whether Congress contemplated potential state liability at all.

50 Brief for Respondents, pp. 12-13.

51377 U.S. at 192.

52 Some might find it difficult to agree that an eleventh amendment right was waived by ratifying the commerce clause since the eleventh amendment was promulgated in 1798, several years after the commerce clause had become the supreme law of the land. I WARREN, op. cit. supra note 4, at 101. The Supreme Court apparently found this fact unpersuasive, as it was not mentioned in the opinion.

53 The same argument was advanced, without notable success, by the plaintiff in that case. 
that ratification of the prohibition of laws impairing contractual obligations, a constitutional provision expressly taking a right away from a state, involves any less a surrender of sovereignty than ratification of the commerce clause, a constitutional provision which may make necessary the removal of a right in the future. Furthermore, by subsequently issuing bonds, the state in Hans could be said to have "consented" to suit. Similar arguments could be advanced in favor of the many plaintiffs who have been unable to recover because of the Hans doctrine. ${ }^{54}$

The Court in Parden distinguished Hans with an ease more apparent than real. The plaintiff in Hans, it was said, had invoked the federal question jurisdiction of the Court. In Parden, "for the first time in this Court, a State's claim of immunity against suit by an individual meets a suit brought upon a cause of action expressly created by Congress." 55 This, of course, is also a matter of federal question jurisdiction. The Court distinguished three cases which had followed Hans by asserting that they were "also commonplace suits in which the federal question did not itself give rise to the alleged cause of action against the state but merely lurked in the background."56 Thus, the Court created a distinction between causes of action created by congressionally enacted statutes and those involving other federal questions-such as basic constitutional issues-and thereby evaded Hans $v$. Louisiana.

The Court's second line of argument proceeded on the assumption that Alabama's immunity was constitutional. The state argued that since Congress could not remove its constitutional immunity directly, it could not do so indirectly by conditioning the extension of the privilege of entry into interstate commerce upon Alabama's waiver of its sovereign immunity. ${ }^{57}$ In support of this argument, an application of the doctrine of "unconstitutional conditions," 58 Alabama re-

54 See cases cited note 23 supra.

55377 U.S. at 187.

$56 \mathrm{Id}$. at 187 n.3. These cases were: Ex parte New York, No. 1, 256 U.S. 490 (1921); Duhne v. New Jersey, 251 U.S. 311 (1920); Smith v. Reeves, 178 U.S. 436 (1900). Duhne v. New Jersey was accurately described by the Court as "a suit against the State to restrain it from enforcing the Eighteenth Amendment to the Federal Constitution, on the ground that the Amendment was invalid." 377 U.S. at 187 n.3. From this description it is apparent that the federal cause of action was not lurking in the background.

57 Brief for Respondents, pp. 14-16.

58 See, e.g., United States v. Joint Traffic Ass'n, 171 U.S. 505, 571 (1898); Interstate Commerce Comm'n v. Brimson, 154 U.S. 447, 479 (1894); Monongahela Nav. Co. v. United States, 148 U.S. 312, 336 (1893). A lengthy examination of the doctrine is not within the scope of this comment. For extensive analyses of the case law see Hale, Unconstitutional Conditions and Constitutional Rights, 35 CoLUM. L. REv. 321 (1935); Merrill, Unconstitutional Conditions, 77 U. PA. L. REv. 879 (1929); Willcox, Invasions of the First Amendment Through Conditioned Public Spending, 41 CORNELL L.Q. 12 (1955); 
lied on cases stating categorically that a legislative body cannot condition the grant of a privilege upon waiver of constitutional rights, even if the privilege could be withheld entirely. ${ }^{59}$ An examination of the cases in this field suggests, however, that such preconditioning is a legitimate exercise of legislative authority as long as the condition imposed is a necessary and reasonable method of regulating the area in which the privilege is granted. ${ }^{00}$ This relationship clearly exists in Parden; the regulation of interstate commerce can reasonably be said to require enforceable rights of action for all workers protected by the FELA. Adopting this view, the Court in Parden dismissed each of Alabama's authorities as "clearly distinguishable because the condition sought to be imposed was deemed by the Court to fall outside the scope of valid regulation." 61

The Court's basic argument, that Congress legitimately conditioned entry into commerce on waiver of immunity and that the state's subsequent action served to waive immunity, is similar whether the basis of immunity is seen as a matter of constitutional or common law. The difference lies in the circumstances under which Congress can set conditions. In Parden it was only necessary to decide that Hans v. Louisiana should be overruled to the extent that it restricted Congress' legitimate conditioning powers, a result most easily reached by a determination that the Hans immunity was based on common law. ${ }^{62}$ However, the Court, by basing its decision on the alternative common law and constitutional law grounds, laid the logical groundwork for finding a waiver of immunity whether the claim of immunity is based on common law sovereign immunity or on the express language of the eleventh amendment. The obvious implication of Parden is that a similar result would have been reached if the plaintiff had been a citizen of another state and if the defendant's immunity had thus been based irrefutably on the eleventh amendment.

Note, Unconstitutional Conditions, 73 HARv. L. Rev. 1595 (1960); Note, Judicial Acquiescence in the Forfeiture of Constitutional Rights Through Expansion of the Conditioned Privilege Doctrine, 28 IND. L.J. 520 (1953). For an excellent criticism of the logical fallacies inherent in both sides of the argument see French, Unconstitutional Conditions: An Analysis, 50 Geo. L.J. 234 (1961).

69 See, e.g., Wheeling Steel Corp. v. Glander, 337 U.S. 562, 571 (1949); Hanover Fire Ins. Co. v. Harding, 272 U.S. 494, 507 (1926); Frost \& Frost Trucking Co. v. Railroad Comm'n of Cal., 271 U.S. 583, 593-94 (1926). Cf. Lafayette Ins. Co. v. French, 59 U.S. (18 How.) 404 (1855).

60 That the Court is moving toward this standard with increasing consistency is suggested by, e.g., American Communications Ass'n v. Douds, 339 U.S. 382 (1950); United States v. Appalachian Power Co., 311 U.S. 377 (1940); Stephenson v. Binford, 287 U.S. 251 (1932); Fox River Paper Co. v. Railroad Comm'n of Wis., 274 U.S. 651 (1927).

61377 U.S. at 193-94 n.11.

62 See text accompanying notes 20-22 supra. 
Where federal jurisdiction is based upon a federal question ${ }^{63}$ it would seem that the reasoning in Parden can be logically extended to overrule sub silentio all of Hans and to negate the eleventh amendment. ${ }^{64}$ It would be possible to find a prior general waiver by the states in ratifying the Constitution and in subsequent specific action such as the issuance of bonds or operation of an interstate railroad. However, the Court attempted to avoid this extreme and to distinguish Hans by interposing as a third precondition to the finding of waiver congressional legislation which could be said to create a federal cause of action.

The future significance of Parden is difficult to predict despite the fact that mechanically the distinction between congressionally created causes of action and other federal questions is unlikely to pose troublesome problems. Since a congressionally created cause of action must involve an area of federal regulation, any liability imposed upon a state must be preceded by the state's entry into the field. Such an entry will necessarily involve some action which a federal court will be able to treat as a waiver of immunity. But the technical feasibility of the distinction does not justify it; there seems to be no reason why state immunity should prevent a suit on a federal question and yet be ineffective against a suit based on a congressionally created cause of action. That the federal courts should be open to a suit under the FELA but closed to a plaintiff whose constitutional rights have been violated is an unavoidable result of the Parden decision, but is so anomalous ${ }^{65}$ that it

63 The area involving federal jurisdiction based on diversity of citizenship is not overruled by Parden. In such cases there is no prior general waiver by the states, as can be said to exist in federal question jurisdiction based on causes of action arising under the Constitution and laws of the United States. Furthermore, under the Erie doctrine, waiver in diversity cases would be a matter of state and not of federal law. See Scott $v$. Board of Supervisors, 336 F.2d 557, 559 (5th Cir. 1964) (rejecting Parden in diversity action); Southern Ry. v. South Carolina State Highway Dep't, 246 F. Supp. 435 (E.D.S.C. 1965) (Parden not cited in diversity case).

Parden was also distinguished in a federal question case which did not involve a congressionally created cause of action. DeLong Corp. v. Oregon State Highway Comm'n, 233 F. Supp. 7 (D. Ore. 1964), aff'd, 343 F.2d 911 (9th Cir. 1965) (declaratory judgment for interpretation of contract to construct an interstate bridge; waiver of state immunity determined by state law).

64 For example, the Court's opinion explicitly linked Hans with the eleventh amendment on several occasions and employed language so broad as to encompass a suit against a state by a citizen of another state: “A State's immunity from suit by an individual without its consent has been fully recognized by the Eleventh Amendment and by subsequent decisions of this Court. But when a State leaves the sphere that is exclusively its own and enters into activities subject to congressional regulation, it subjects itself to that regulation as fully as if it were a private person or corporation." 377 U.S. at 196.

$65 \mathrm{Mr}$. Justice Brandeis, writing for a unanimous Court in Lynch v. United States, could perceive no such distinction: "The sovereign's immunity from suit exists whatever the 
may not be tolerated by the courts. Once the distinction is rejected, the central constitutional question must be squarely faced.

The reasoning of the Parden decision seems to apply to all constitutionally enacted federal statutes which create private causes of action. Despite this apparent breadth, the number of congressionally created causes of action ${ }^{66}$ entitled to the benefit of Parden's reasoning may be relatively small, since some statutes exempt states from coverage ${ }^{6 \tau}$ and some only authorize actions brought by the United States or one of its agencies. ${ }^{68}$ There are several existing causes of action, however, to which Parden could apply. Because the Jones Act specifically adopts FELA provisions, the Parden analysis is clearly applicable. ${ }^{69}$ The implied consent rationale is also relevant to the private action for treble damages under federal anti-trust laws when a state is the defendant. ${ }^{70}$ The application of implied consent to state immunity need not be confined to areas under Congress' commerce power; Parden does not compel such a limitation. For example, federal patent statutes create private causes of action, ${ }^{71}$ which could be brought against a state, perhaps under respondeat superior in connection with the activities of its agents. The patentee could argue persuasively on the strength of Parden that a state, in ratifying article I, section 8 of the Constitution, surrendered any portion of its sovereignty which would interfere with congressional regulation pursuant to that provision; and that Congress preconditioned state action $^{72}$ in the regulated field upon amenability to suit in the federal

character of the proceeding or the source of the right sought to be enforced. It applies alike to causes of action arising under acts of Congress . . . and to those arising from some violation of rights conferred upon the citizen by the Constitution." 292 U.S. 559, 582 (1934).

66 This term should not be taken too literally. The FELA cause of action "expressly created by Congress," which was involved in Parden, can justifiably be viewed not as an entirely new cause of action but as a significant modification of an already existing common law right of action. The dissent in Parden viewed it as such. 377 U.S. at 199. A cause of action would seem to meet the requirements of Parden if it is either wholly new or represents a substantial departure from an already existing common law action.

67 For example, two sections of the Taft-Hartley Act exempt states from the coverage of that act. See 61 Stat. 137, 161 (1947), 29 U.S.C. $\$ \$ 142$, 152(2) (1964). The same effect is achieved by the Longshoremen's and Harbor Workers' Compensation Act, which precludes compensation under the act for an officer or employee of any state. See 44 Stat. 1426 (1927), 33 U.S.C. § 903(2) (1964).

68 For example, the provisions of the Federal Safety Appliance Act create a right of action in the Interstate Commerce Commission and do not authorize private suits. See 29 Stat. 85 (1896), 45 U.S.C. \& 6 (1964).

69 See 41 Stat. 1007 (1920), 46 U.S.C. § 688 (1964).

70 The Clayton Act provides: "Any person who shall be injured in his business or property by reason of anything forbidden in the antitrust laws may sue therefor in any district court of the United States ... and shall recover threefold the damages by him sustained ... ." 38 Stat. 731 (1914), 15 U.S.C. § 15 (1964).

7135 U.S.C. $\$ \S 271,281$ (1964).

72 The plaintiff's major difficulty in such an action would be to isolate some act of the 
courts, regardless of the basis of the immunity.73 $\mathrm{A}$ similar argument could be made in a copyright infringement action. ${ }^{74}$ Thus, it is apparent that the periphery of the Parden rule may be the subject of some uncertainty.

\section{Conclusion}

In Petty v. Tennessee-Missouri Bridge Comm'n and Parden v. Terminal Ry. of Alabama State Docks Dep't the Supreme Court adopted a new approach to the problem of state immunity from suit in federal courts. The curiously limited nature of the holding in Parden is probably the result of a compromise between the Supreme Court's distaste for the results of the sovereign immunity doctrine and its hesitancy to contravene the eleventh amendment. It is clear, however, that if Parden is followed to its logical conclusion, the eleventh amendment will have been relegated to the constitutional limbo already occupied by the ninth and tenth amendments.

state which would be analogous to Alabama's operation of a railroad in interstate commerce and which therefore could be considered as entry into the congressionally regulated area. The difficulty might not be insurmountable.

Suppose state agents are involved in a construction project requiring underwater blasting. They construct a small portable dam to still the water in the blasting area. The patentee of a similar dam sues for infringement. This was essentially the factual situation of Cammayer v. Newton, 94 U.S. 225 (1876). Since respondent superior applies, might not the plaintiff argue that the state entered the regulated area by initiating the construction project and thereby incurring potential liability for the infringements of its agents, just as Alabama incurred potential liability by initiating the operation of the railroad. Given the disfavor with which the Court views sovereign immunity, the Court might accept the argument.

Suppose the state enters into an agreement with an independent contractor in which the latter agrees to manufacture certain articles for the state. In the course of the manufacture of the articles, a patent is infringed. Since "it is obvious that one may infringe a patent if he ... [has] the offending articles manufactured for him by an independent contractor," Crowell v. Baker Oil Tools, Inc., 143 F.2d 1003, 1004 (9th Cir. 1944), the plaintiff might claim that the making of the contract constituted "entry."

73 If the claimed immunity were viewed as constitutional, it could be argued that the provision of a remedy for one whose patent was infringed is a valid regulatory purpose which Congress can secure by waiver of constitutional rights upon entry by the state.

7417 U.S.C. \$ 101 (1964). 